\title{
ンポジゥム 食道及び気道における自律神経支配の基礎と臨床
}

\section{下咽頭・食道と自律神経（臨床的観察）}

*川久保淳

自律神経と食道の関係を臨床的に検討する場 合, 広義の自律神経失調という比較的軽い病態 についても追求することが必要だと考えられ る。

そこで，私は自律神経の失調が認められる下 咽頭・食道の異常感症例を検査対象として主と して「レ」線連続撮影 (35 mm Oderka mirrowa camera), 又一部症例に「レ」線テレビ, 食道内圧測定 (Open-tip fukuda MR 150) 及び ファイバースコープ (町田) を併用して器下時 の動態について追求した。

（1）下咽頭・食道異常感者の食道動態

異常感者 200 例, 正常対象63例についてバリ ュウム $30 \mathrm{cc}$ (Barex-molt……以下 $\mathrm{Ba}$ と省略)
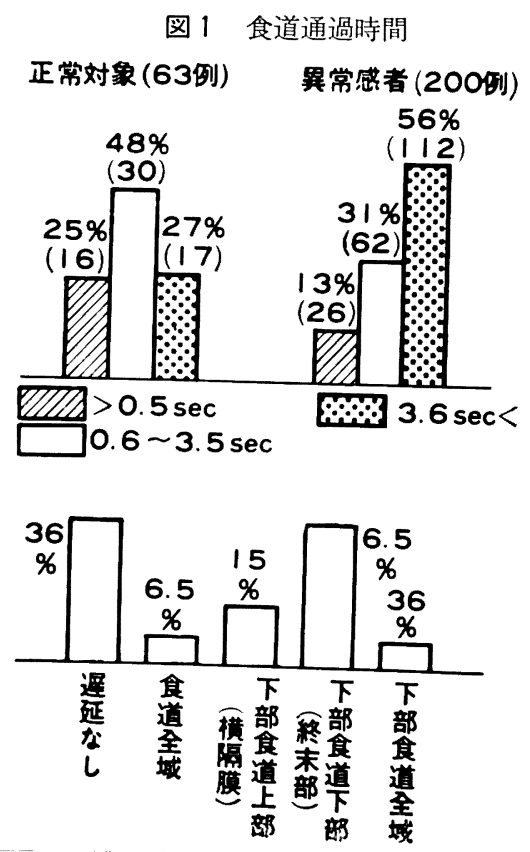

* 東京医科大学耳参咽喉科教室講師 (主任 白岩俊雄教授)
図2 食道「レ」線像の分類

\begin{tabular}{|c|c|c|c|c|}
\cline { 3 - 5 } Normal & $\begin{array}{c}\text { Contrast } \\
\text { group }\end{array}$ & $\begin{array}{l}\text { Abnor- } \\
\text { mal } \\
\text { type } \\
\text { group }\end{array}$ & $54 \%$ & $\begin{array}{l}\text { Max. } \\
\text { dia- } \\
\text { meter }\end{array}$ \\
\hline \multirow{2}{*}{$\begin{array}{c}\text { Abnormal } \\
\text { from }\end{array}$} & $\begin{array}{c}\text { Asthenic } \\
\text { type }\end{array}$ & 41 & $43 \%$ & $2.6 \mathrm{~cm}$ \\
\hline $\begin{array}{c}\text { Dilated } \\
\text { type }\end{array}$ & $\begin{array}{c}\text { Spastic } \\
\text { type }\end{array}$ & 0 & 6 & 2.9 \\
\hline
\end{tabular}

図 3

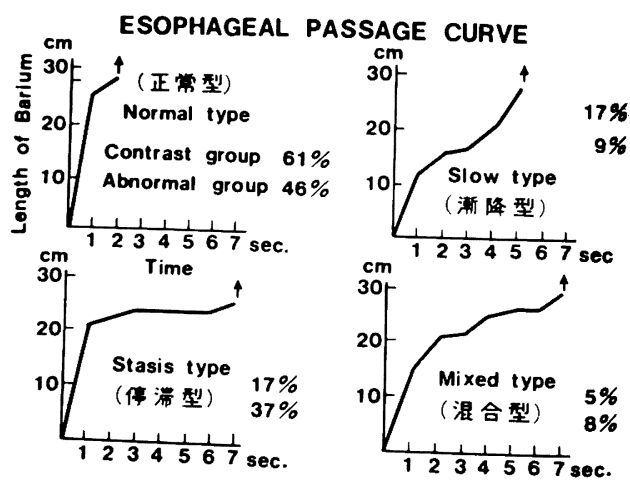

を一息に讌下させた際の $0.25 \sim 0.5 \mathrm{sec}$ 間隔の 「レ」線撮影を行い，之を食道入口部（第 6 頸 椎）より噴門迄の食道通過時間, 横隔膜より胃 内迄の噴門部通過時間及び排出終了時間を夫ヶ 測定した。

その結果図 1 に示すように異常感者では食道 通過時間の延長する事が多く，こ㞦は噴門通過 時間とも関連し，嬖々下部食道に $\mathrm{Ba}$ が停滞す る事が認められる。

又「レ」線所見の上からも図 2 のように時に 
異常な拡張や痤性の所見が認められた。

この $\mathrm{Ba}$ の通過を図 3 の様に横軸に時間をと り, 縦軸に第 6 頸椎から $\mathrm{Ba}$ 尖端迄の長さを経 過を追つて曲線として画くと, 正常型, 漸降 型, 停滞型, 混合型の四型に大別できる。

更に Ba 充盈所見の $0.5 \mathrm{sec}$ おきの重複描画に よる食道壁の動きを図 4 の様に光進型，減弱型 及びその中間の中間型に分類しここれ前述の 通過曲線と比べてみた。

その結果（図 5 ）食道壁の動きは各々の通過 曲線型でそれぞれ特長がみられるが，特異な事 は，同じ様に下部食道に停滞するものでも，食 道壁の著しく拡張する例では食道壁の動きが殆 んど認められない事である。(図 4,5 )

図4重複描画（0.5 sec おきの食道壁の動き）

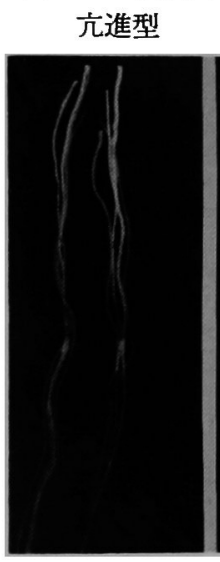
減弱型 拡張型

図 5 食道動態分類上食道壁の運動

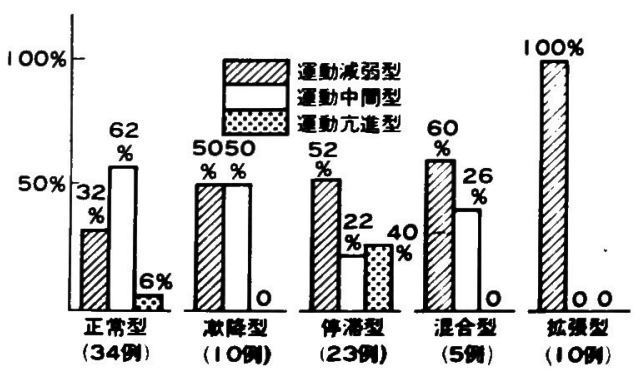

この事実から食道動態を綜合的に通過と運動 の両方から観察する場合, 通過曲線の 4 型に拡 張型を加えた 5 型が分類できる。

勿論, 通過時間の延長そのものは, 必ずしも 病的な変化とはいえないるので, 正常者でも年
令と共に通過時間が延長する傾向にある。

又全身の自律神経の関係からこれをみると， 図 6 の様に，交感性緊張と関連するという血圧 変動係数の異常值を示すものでは，食道通過時 間の延長する者が若干多い様である。

なお，これら異常感者の食道動態の詳細につ いては協同研究者橋本により近日報告されよ う。

図 6 全身自律神経機能と通過遅延 （通過遅延者 \%)

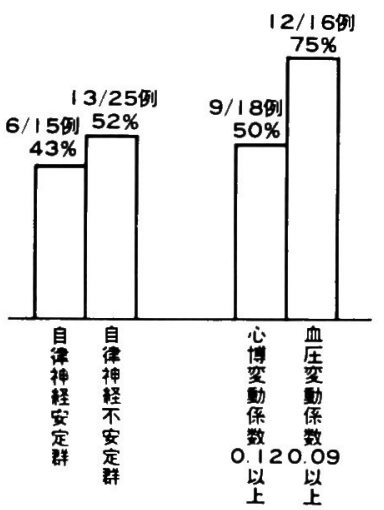

\section{（2）食道動態分類の意味するもの}

さてこの様な食道動態の分類と，自律神経薬 に対する反応との関連をメコリール，アトロピ ンを用いて検討してみた。

ここの場合，投与量が多いことに基うくく過剩 な反応による混乱を考慮し，また可及的に生理 的な刺戟閾に近いという意味から，0.3cc 皮下 注射といら微量投与を行つた。そして投与 8 分 後の通過時間の変化を $1 \mathrm{sec}$ 以上の短縮或いは 延長を夫々促進例，遅延例として検討した。

因に正常人においては図 7 の点線の様に通過 曲線の型の上では予期する反応が示されるが， 通過時間の上では全く変化は現れていない。

メコリール注射による通過時間の変化を検討 すると, 図 8 の様に個体によりそれぞれ促進, 不変, 遅延と一定の反応を示さない。

これを動態分類からみると下部食道に停滞す るものでは更に通過が遅れる, 反之, 正常型で は遅延例は少く, 拉張型では遅延例は 1 例も無 W。 
気食会報 -19 巻

図 7 薬物による通過曲線の変化(正常)

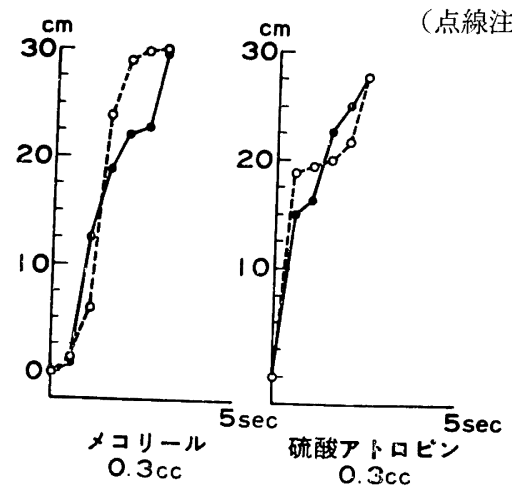

図 8 メタコリン $0.3 \mathrm{r} .1$ 皮下注射 (37例) 8 分後通過時間の変化

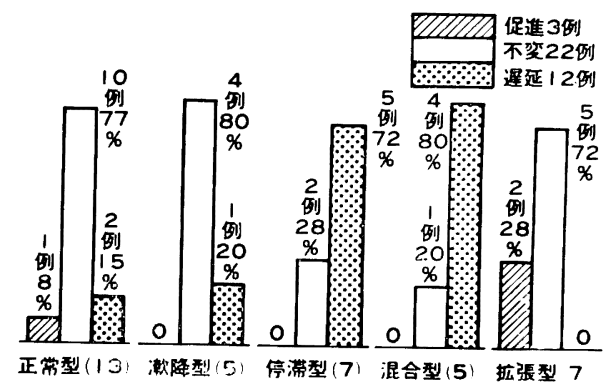

すなわち食道に惹き起された反応の立場から これをみると, 正常型では僅かのメコリールに 上手く適応して変化を示さないのに, 停帯型で は元来の Vagotomia の存在, 或いは対応する 交感性の反応低下，又拡張型では更に副交感性 の反応の低下を示唆しているょうに思われる。

アトロピンでは停滞型纤促進的に反応してお り，こ机出その停滞が Vagotomiaによつてい たものか, 或いは福原氏のア七チルヒョリンー アトロピン奇異拮抗抑制て説明できるものか, いずれにしろ局所の副交感性の緊張が存在する 事を示焧しており。之に対し拡張型では通過仿 かえつて遅延する傾向が認められた。(図 9)

さて Aschner, Czermack の反射消化管に おいても局所の自律神経の状態で, 促進的に も，抑制的にも両様の反応が起る事が実験的に 証明されている。食道通過においても図10に示 す様に停滞型では遅延として, 又メコリールで 賦活した拡張型でも遅延的に反応している。
図 9 硫酸アトロピン $0.3 \mathrm{ml}$ 皮下注射 (20例)

8 分后通過時間の変化

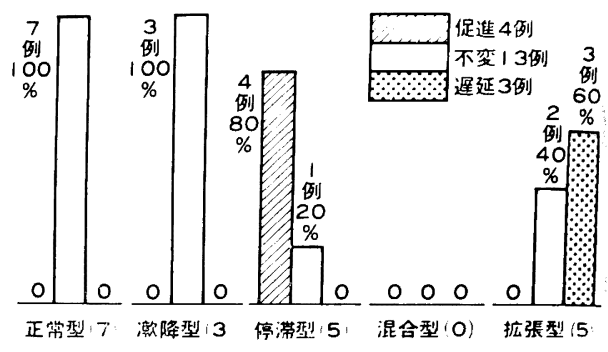

図10 ツェルマック施行による通過時間の変化

\begin{tabular}{|c|c|c|c|c|c|c|}
\hline 型 & 正常 & 渐降 & 停滞 & 混合 & 拡張 & 計 \\
\hline 促進 & 0 & 0 & 0 & 0 & 0 & 0 \\
\hline 不变 & 3 & 2 & 3 & 0 & 4 & 14 \\
\hline 遅延 & 0 & 0 & $\begin{array}{c}20 \% \\
40 \%\end{array}$ & 0 & 0 & 2 \\
\hline 棓 & 3例 & 2例 & 5 5例 & 0 & 4 4例 & 16 例 \\
\hline
\end{tabular}

×タコリン $0.3 \mathrm{ml}$ 皮下注 10 分后ツェル マック施行

\begin{tabular}{|c|c|c|c|c|c|c|}
\hline 促進 & 1 & 0 & 0 & 0 & 0 & 1 \\
\hline 不㚆 & 3 & 0 & 0 & 0 & 0 & 3 \\
\hline 遅延 & 0 & 0 & 1 & 0 & 1 & 2 \\
\hline 計 & 4 4例 & 0 & 1 例 & 0 & 1 例 & 6 6例 \\
\hline
\end{tabular}

これは両者の交感性の反応低下と副交感性の 緊張の累加で説明できる訳で, 先の薬力学的検 査の成績と一致している。

この事実はファイバースコープ鏡下で，メコ リール注射後の停滞型食道に, Aschner 法を施 行すると, 噴門部に著明な緊張状態の発現を認 めた事からも裏付けられる。

食道内圧ひき妒曲線では, 図11のように, 停帯型は噴門部高圧帯の上昇として, 拡張型 は, 軽度の Achalasia に近い曲線として, 平坦 な噴門圧を示し, 又漸降型では入口部, 頸部食 道の圧上昇として変動がみられ, 下咽頭, 頸部 
食道の異常動態と考えられる。

メコリール注射によつて一般に食道内圧は上 昇する傾向を示し，停滞型では噴門圧は急峻化 して来るが，拡張型では比較的なだらかな圧上 昇として，丁度停滞型のひき奴曲線に類似し た所見を示し，それぞ机の動態の特徵と，それ らが相互に移行しうる事実を示唆している（図 12)。

図11食道内圧ひき妒曲線

（上）各種食道動態

（下）症例のメコリール注射后の変化

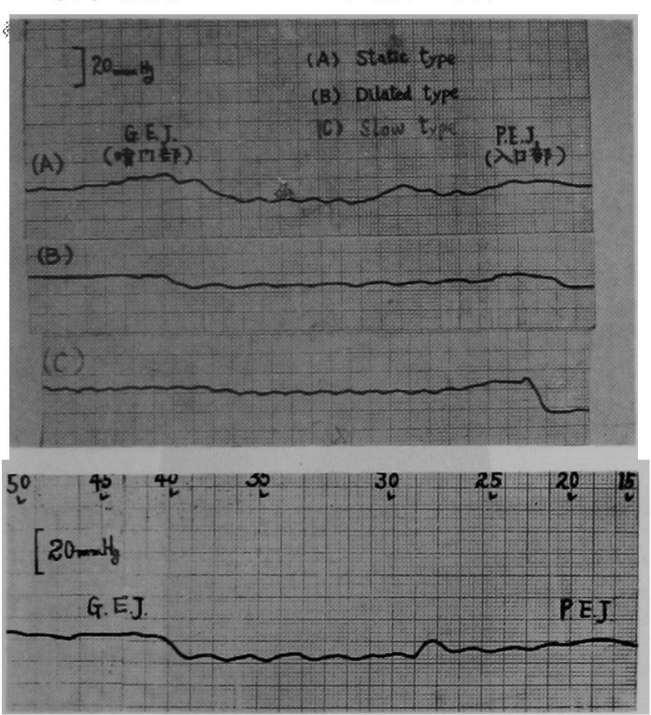

図 12

Dilated type (軽度)のひきれき曲線
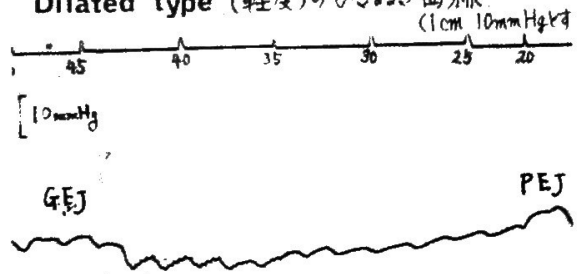

上同症例のメコリール0.3c注射后の变化
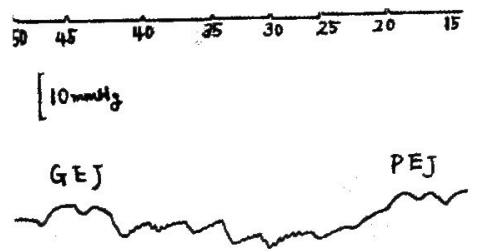

又下部食道圧を経過を追つて測定してみる と，0.3ccメコリール皮下注射による昇圧は注 射直後より始まり，4 -5 分で漸次著明とな り, 少くとも13分後迄の間には内圧の逆転, 或 いは急墜という現象は認められなかつた。

\section{（3）疾患への移行}

つづいて下部食道の動態と疾病の関係を $\mathrm{Ba}$ の排出形式から検討してみた。

排出形式は図13の様にA）正常型，B）搾出 型，C）無弛緩型に大別きる，元来食道通過の 遅れている症例で流，その $\mathrm{Ba}$ の残存とあいま つて，上下に搾り出すB型を示寸事が多く，時 に停滞型食道では，この際下部食道の Phrenic ampula が裂状に拡張する所見 $\left(\mathrm{B}_{2}\right.$ 型 $)$ が認め られる。

この拡張所見を仔細に検討寸ると, 裂孔へル ニアの前政と考えられている所謂下部食道輪が 5 例に認ぬられ，更に1例では明らかなールニ アへの移行型（沪斗状形成）が認められた事か らも，停滞型の持続と裂孔へルニアの成立との 関連が示㤎されている。

図13 排出基本型分類 (176例)
A 正常型 $(58 \%)$
B控出型 $(39 \%)$
$\mathrm{B}_{1}$ 球状拡張

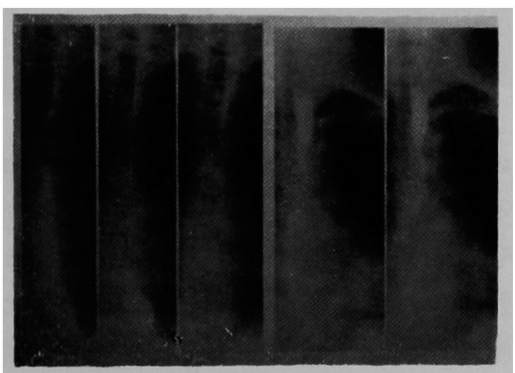

$\mathrm{B}_{2}$ 霬状拡張 $\quad \mathrm{C}$ 無弛緩型 $\left(3{ }^{\circ}, o\right)$

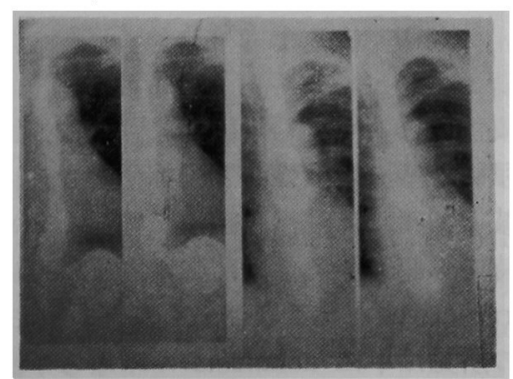


気食会報一 19 巻

一方, これらの異常動態と, Achalasia 或い は特発性食道拡張症の名で知られている病態と は，本質的な違いがある。それは噴門の通過は 遅れても必ず噴門は弛緩する事であり, 又メコ リールによる過敏な反応を惹き起さない事であ る。

しかし，仔細に検討すると稀に拡張型食道に 極めて軽い無弛緩の傾向（排出型C）が認めら れることもある。

これは亦, diffuse spasmus が拡張型食道に 発生する事が多く，（図14）又Achalasia 発症前 の搪張型食道の存在から考えて, 拡張型を介し ての神経筋接合部障害へと移行して行く事も推 察される。

図14 連続的な観察で拡張型食道に diffuse spasms がみられる。

㹡張型

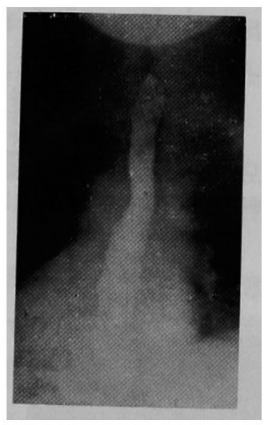

右症例の痓性所見

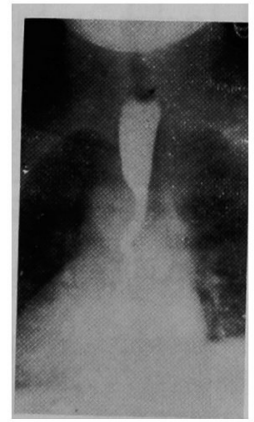

この意味で Achalasia 症例に就いても検討し てみると、この場合食道には一見運動の六進を 思わせる異常収縮が発現する。先述のメコリー ル注射後にファイバースコープ下で明瞭な二種 類の激しい収縮一噴門部から搾り上げる様な大 きな収縮, 及び噴門部を漣の様に走る細かい収 縮一が認められる。なお亦単に 200 倍稀䣋メコ リールで局所を灌注するだけでも異常収縮の発 現を認める事ができる。

又安静時に於いても（図15）食道内圧は指尖 の容積脉波基線の陰性波と同期する食道内圧の 陰性波と, それに続く収縮波の頻発を認め, 哚 呼吸時の脉波上り考えて, 胸腔内圧に反応する hyperreactive な異常収縮とも考えられる。 この所見は単に achalasia のみならず図16の
図 15

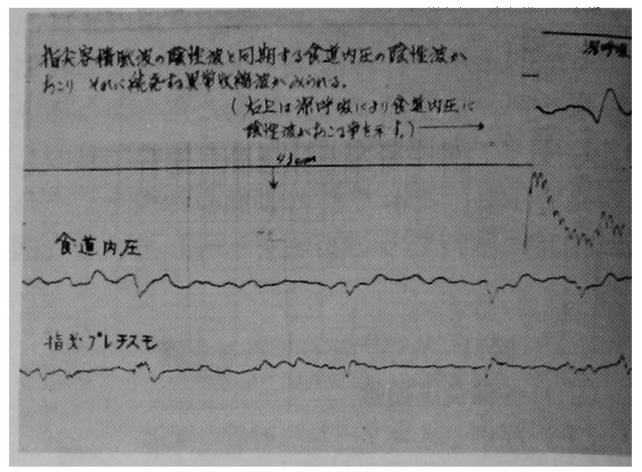

図16気管支癌症例の機能的食道通過障害

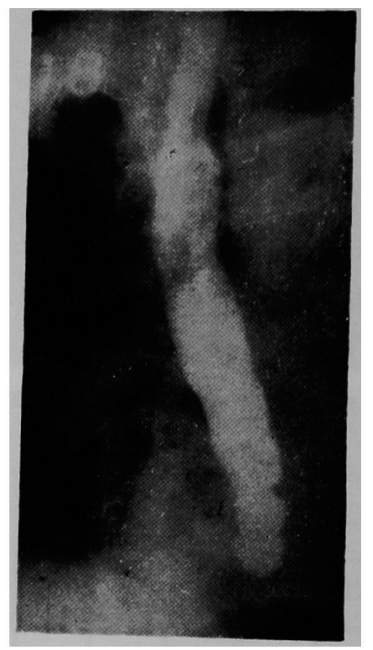

気管支癌の Anoxaemia と食道偏倚に基づく機 能的な高度の应性の臙下障害をも説明できるも のと思われる。な初本症例は Rn seeds の刺入 により閉塞性腫瘤の消失と共に, 原病の進行に もかかわらず食道の通過障害は消失していた。

一方 Aschner, Czermack はこのような異常 収縮を抑制する。すなわち Achalasia にみられ た tired spasms, も terialy contraction,$い$ ずれも Czermack, Aschner で消失してしま 5 。

食道内圧からこれをみると図17の様に，メコ リールで誘発された異常収縮は Aschner によ り抑制され, 且つ $5 \mathrm{mmHg}$ 程内圧も低下する。 反之, 停滞型食道のメコリールによる圧上昇 に対しては Aschner は逆に $4 \mathrm{mmHg}$ 程内圧を 上昇させる。 
図17 Aschner による食道内圧の変化
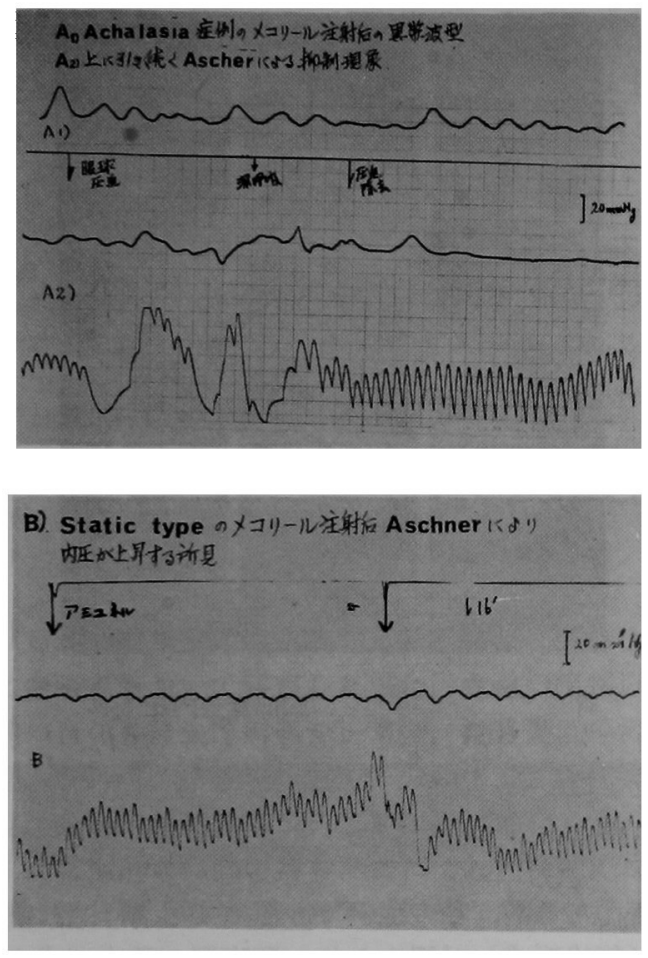

すなわち Achalasia にみられる異常収縮は hyper-reactive な反応と考えられ，Aschner， Czermack はな䇳存する交感性の抑制として 作用したものと推察できる。

\section{（4）下咽頭・頸部食道の病態}

上部食道と下部食道では構成する筋肉が違う 為，その反応も亦異なつて来る。

メコリール内圧曲線に於いても噴門圧は急峻 化する傾向にあるが，入口部高圧帯は頸部食道 全般の斜の圧勾配として, 平滑筋の可塑性と横 紋筋の弾性体の違いを示している。（図18）

又従来, 頸部食道の交感性支配にも問題があ り，影響なしとするもの，促進的に働くとする もの等色々である。図19の Achalasia 症例の $0.25 \mathrm{mg}$ インデラール静注による $\beta$ 遮断効果を みると, 食道内圧の六進に対応する潜在する入 口部の緊張が，限局する圧上昇として認められ る。

これは亦一般にインデラールは食道入口部に 限局する圧上昇を示す事実からも，入口部にお いては強い交感性の抑制が作用している事を考
図18 メコリール内圧曲線

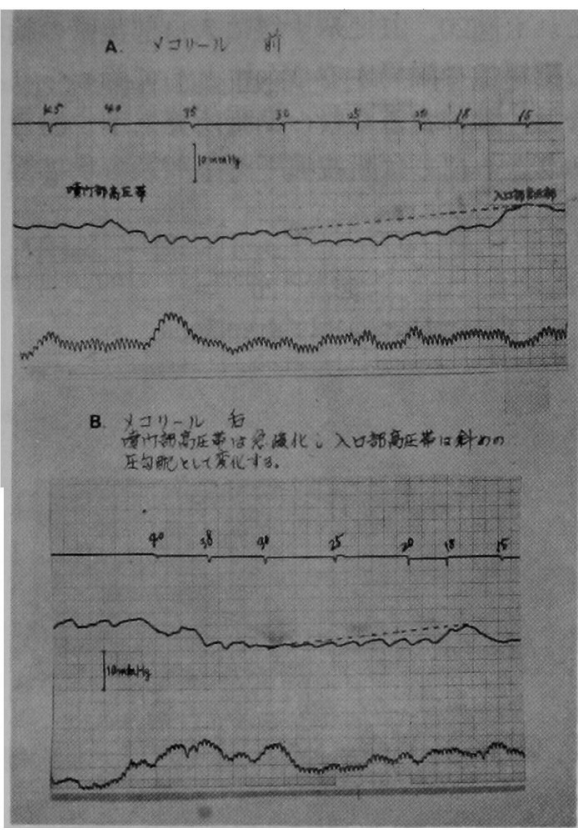

図 19

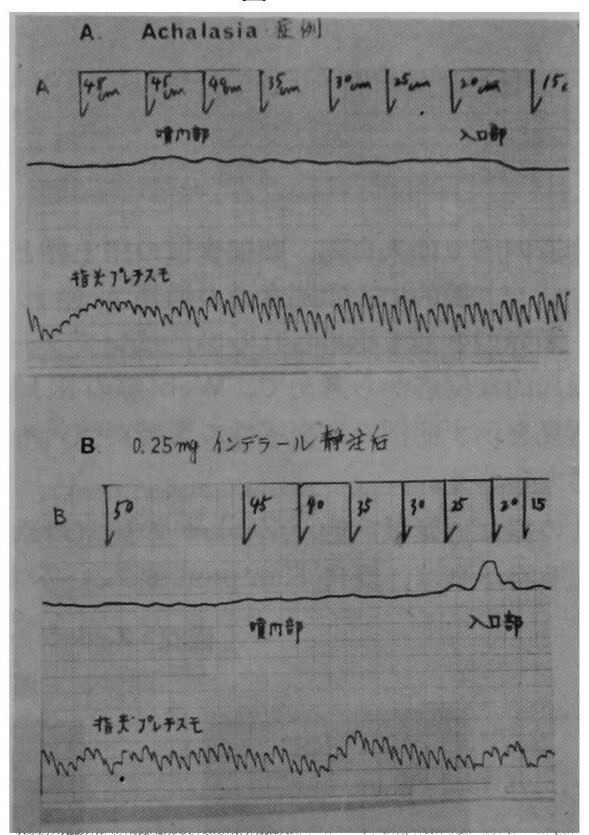

えさるせものである。

この意味から異常感者96例の苝下第 II 相を 「レ」線連続撮影により検討すると，16例16\%に 持続する過緊張による所謂 Cricopharyngeal 
気食会報一 19 巻

dysphagia の所見が認められる。

これも図 $20 ， 21$ に示寸様に入口部後壁の輪状 筋の肥厚像や限局するWeb として認められる 場合と, 頸部食道全般の緊張所見を示す場合と があり，しばしば断続嚥下や下咽頭垔状拡張を 伴つている。

\section{図 20}

Cricopharyngeal dysphagia

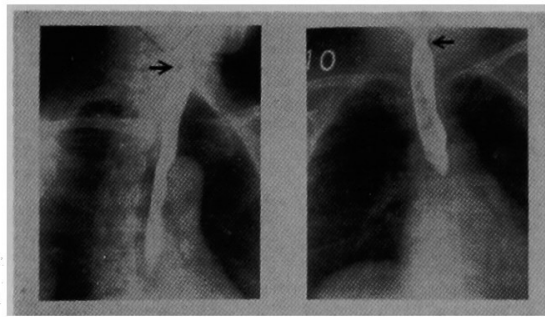

偏側性の Web

断続櫒下

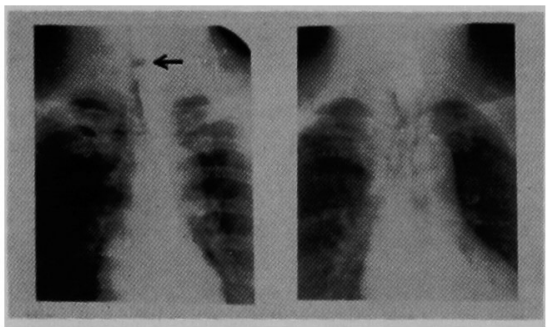

食道内圧では入口部, 頸部食道の圧上昇とし て，「レ」線的にも頸部食道の通過が遅れる 為, 漸降型として認めら扎る゙，インデラール の限局的な反応から考えて, Web 等の限局的 な所見を示す症例では交感性の影響が強いもの と考えられる。

この様な過緊張病態が Zenker の憩室の原因 となり得る事は，既に Hampton 他二, 三の報
图21頸部食道の通過遅延所見
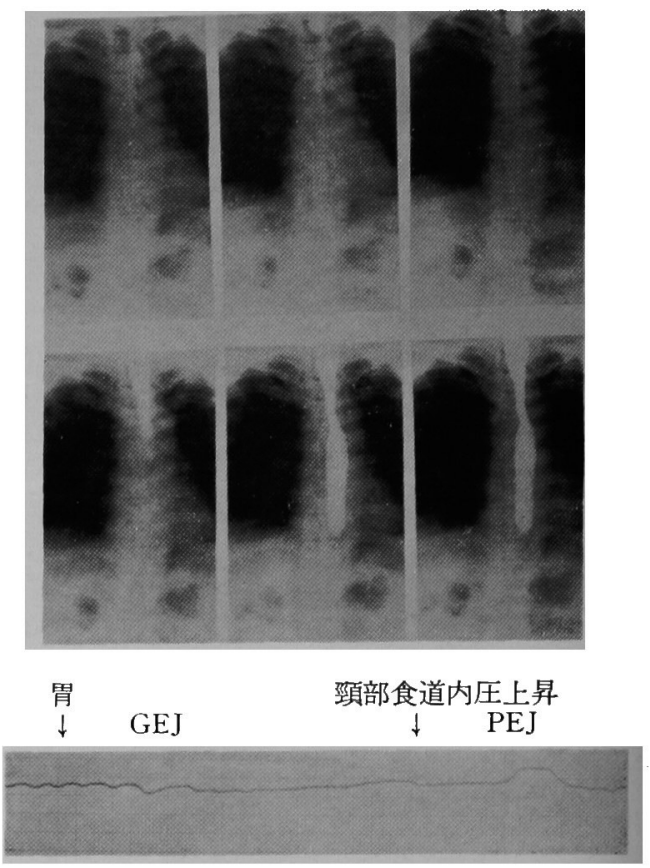

告があるが，私の症例でも極めて早期の熄室 （栜状形成）が認められ，漸降型と憩室の成立 との関係を示している。(図22)

以上の成績から総括的に考察して, 食道の異 常動態と主として自律神経薬による食道の反応 との関係を模式的に表示してみた。（図23）

勿論, 臨床的に自律神経を取扱う場合, 複雑 な人体の機構から考えても，単一な条件を作製 できる動物実験と異なり，その出現する現象は かなり複雑であり, 簡単に意味附けする事は難 しく, 又諸種の刺激を附加して検討する場合, 当然自律中枢の反応も亦顧慮する必要があろ う。

図22 Zenkel の䄭室への移行 (欶状形成)

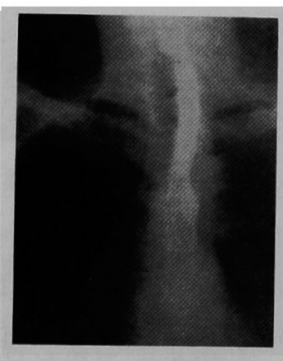

連続撮影所見
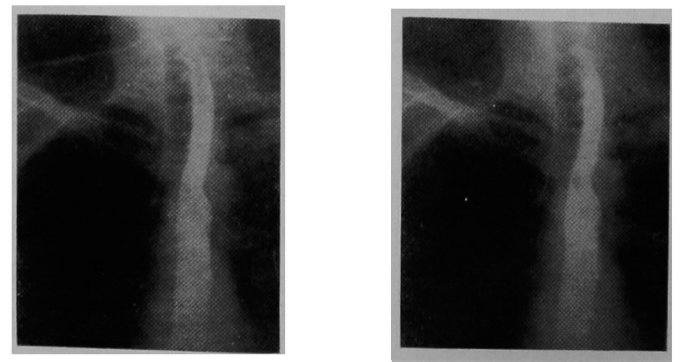

$26-26$ 


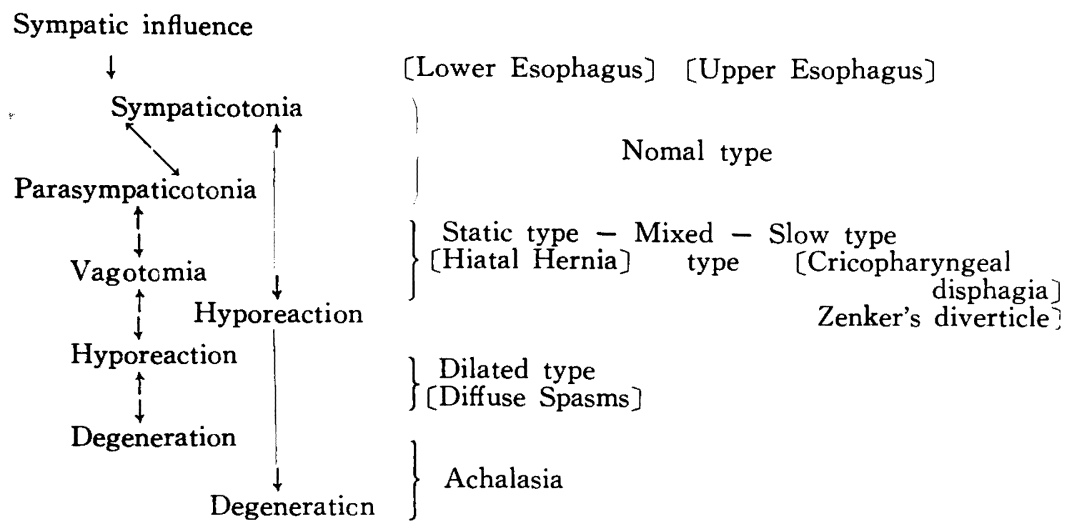

しかし, 食道の通過時間と云う臓器の反応性 に主眼点をおいて観察した場合, 食道の疾病以 前の自律神経失調病態を正常型, 漸降型, 停滞 型, 混合型, 拡張型の五型に分類することによ り，それぞれの動態が自律神経の反応の上から も, 特徵的な傾向を持ち, 更にそれの持続, 或 いは進行により, 様々な不可逆的な病態を惹き 起すことが考えられた。

（共同研究者：橋本東洋, 白岩恒男, 渋谷晋市郎)
（本論文は第19回日本気管食道科学会のシンポジ ウムに於ける講演要旨を補綴したものである。本シ ンポジウムの機会を御与え下さつた高須総会会長に 深謝致します。

又終始御㤅篤な御指導, 御校閲を賜つた恩師白岩 俊雄教授に厚く御礼申し上げます。

なお, 本研究の当初より御協力を頂いた上記共同 研究者の諸氏, 及厚生中央病院, 院長故篠井金吾教 授, 外科佐野副院長, 内科田胡部長, 放射線科吉田 部長 成人病棟 松井・藤田両博士, 他医局の諸氏 に束心より感謝致します。) 
ABSTRACTS

\section{Studies on the Effects of Auto- nomic Nervous System Upon Deglutition by Cineradiographic and Digital Analyzing Method}

\author{
T. Tanahashi, M.D. \\ Nagoya University School of Medicine
}

Cineradiographic recording and its digital analyzing method were usefull to do detailed analysis of deglutition. In this study were done the cineradiographic examinations on normal and pathologic subjects and dogs under following conditions, adrenaline, ryegostione, pilocarpine or atropine injection. For the hypothalamic experiments were used normal adult cats and dogs, which were operated under anesthesia with Nembutal. A stimulus electrode was inserted into the hypothalamus to stimulate directly. Under the rectangular electrostimulation (3-7 volts, 0.1-2 m sec. 7-200 c.p.s.) was done the cineradiographic recording. Cineradiograph was analysed with digital analyser and was recorded with digital printer. According to the experiments, results were as follows. The second stage of deglutition was not altered with these drugs. Cardiac resistance and lower esophagial motility of normal subjects were reduced with atropine but were strongly raised with pilocarpine. Adrenaline and ryegostine altered them only slighly. In the pathologic subjects it was quite different, that is, lower esophageal motility was strongly reduced with atropine but not so raised with pilocarpine (Sceleroderma and Myasthenia gravis) and was slighty increased with ryegostine (Wallenbergs syndrome). Cardiac sphincter was opened and lower esophageal motility was incresed with rectangular elec- trostimulus of the ventromedial hypothalamic nucleus. Cardiac sphincter was closed and lower esophageal motility was suppresed with rectangular electrostimulus of lateral hypothalamic nucleus.

\section{Clinical Observation of the Hypo- pharynx and Esophagus in Rela- tion to the Autonomic Nervous System}

\section{Z. Kawakubo, M.D. Tokyo Dental College}

Patients of pharyngopathy with vegetative stigmata, i. e., those with abnormal sensation in the hypopharynx or the esophagus were studied using serial roentogenography technic, and intraesophageal electric pressure (open tip) in some cases. Subjects studied were 200 abnormal cases and 63 control cases without pharyngopathy.

The results are as follows :

1) Esophageal motility was classified into 5 types, normal type, slow type, static type, mixed type and dilated type, by esophageal passage curve and esophageal movement.

2) In relation to esophageal motility and effect of a $0.3 \mathrm{cc}$ mecholyl or atropin sulfricum (intracutaneous injection), it was conjectured that static type is vagotonic (hyper-kinetic) and dilated type is hyporeactive. The effect of Aschner, Cermack and change of intraesophageal pressure also confirmed it.

3) It was also suggested that subcnical abnormal motility may be able to undergo a change into a manifest disease, i. e., Zencker's divertikel, hiatal hernia, and achala- 
sia e.t.c. Achalasia showed hyperreactive contraction and it was restrained by Ascher and Cermack.

4) X-ray films of the slow type showed various crico-pharyngeal disphagia. It was found that the reaction of medicament was different in upper and lower portion of the esophagus due to the anatomical difference of muscular structure, and 3-block-effect of $25 \mathrm{mg}$ intravenous injection of internal was limited in cricopharyngeal region

Finally, the relation between esophageal motility and autonomic nervous system was discussed precisely from the above mentioned facts.

\section{Studies on the Tracheo-bronchial Secretion \\ - Especially Upon the Auto- nomic Control -}

\author{
H. Maekawa, M.D. \\ Osaka City University Medical School
}

This experiment was made to investigate the relationship of the autonomic control to the secretory function of the trachea and bronchus. The results were as follows :

There are some evidences on histological study that the tracheal glands receive the autonomic control, however the goblet cells in the tracheal mucosa work in response to the stimulation on the mucosa indipendently of the autonomic control.

It is clear from the findings of Suzuki's nerve stain that the peripheral parts of autonomic nerve are degenerated by section of the bilateral vagi, and are unchanged by the autonomic drugs.

The enzyme activities - acid phosphatase, succinic dehydrogenase and glucose-6-phosphate dehydrogenase - in the tracheal glands increase and decrease with the secretory function.

In microscopic movie and electronmicro- scopic study, it was found that secretory mechanism in the tracheal 'gland cells are carried out by mean of eccrine type (IV type) and the cycle of this mechanism is quickened by pilocarpine injection.

Some components in the tracheo-bronchial secretion, i.e. sodium, potassium, chlorine, soluble protein and glucosamine were determind and Disc electrophoretic study of the fluid was performed. These results suggest that alteration in the various components of the fluid is less as compared with increasing in volume of the fluid at parasympathicotonic state

\section{Autonomic Innervation of the Esophagus and Airway (Histochemical and Clinical Studies)}

\section{Uono, M.D.}

The 3rd Department of Internal Medicine, Faculty of Medicine, University of Tokyo

For the investigation on neurohumoral theory, I have studied histchemically the distribution of monoamineoxidase (MAO), noradrenaline fluorescing substance (NAdF1) and acetylcholinesterase (AchE) in various tissues. The hypothesis thereby was that neuron with $\mathrm{AChE}$ activity is cholinergic, and with MAO activity and NAd-F1 is adrenergic. In the course of study, however, some nerve cells with high activity of MAO were found to show marked reaction not only in cytoplasm, but also seemingly in nucleus. Sympathetic ganglia consist mainly cells of this "nuclear positive" type and this type was supposed to be the characteristic feature of adrenergic nerve cell.

In muscle layer and gland cells of esophagus, MAO activity was moderately positive and AChE activity was almost negative, while cholinergic and adrenergic nerve fibers 